\title{
The Delivery of Service in Forming the Image of the Hospital and Patients Satisfaction to Gain Patients Loyality in Kajuruhan Kepanjen Hospital Malang Regency
}

\author{
Mamik Ferry Kriswandana Umi Rahayu \\ Department of Environmental Health, Health Polytechnic of Surabaya, Indonesia
}

\begin{abstract}
Kajuruhan Kepanjen Hospital Malang Regency is the only hospital possessed by Malang Regency. The competition among hospitals is getting tighter along with the appearance of private hospitals. The success of hospitals is caused mainly by the delivery of service, especially the service, tolls, and personals because hospitals as service industries have given good services for their patients so that the patients will be loyal. Data collecting method is by a field observation, i.e. distributing the questionnaires and interviewing 210 respondents (patients of Kajuruhan Kepanjen Hospital Malang Regency). Then the data was processed and analyzed by using Structural Equation Modeling (SEM) method, with AMOS software. The result of data analysis shows that the delivery of service has positive and significant influence to the image of the hospital but it does not have significant influence to patients satisfaction. The image of Kajuruhan Kepanjen Hospital Malang Regency has positive and significant influence to patients satisfaction and loyalty. Patients satisfaction has positive and significant influence to patients loyalty.
\end{abstract}

Keywords: Delivery of Service, Image, Satisfaction, Loyalty.

\section{INTRODUCTION}

\subsection{Background of The Problem}

The industry of hospital service is basically socioeconomic, i.e. in addition to emphasizing the application of social values; it must also consider economic principles in carrying out its activities. This is clearly shown in in a private hospital in which the financial resources or the funding come from donors or investors who expect that their investment can be returned, and possibly it is expected to gain profits. The success go a hospital is determined by the service provided mainly tools quality, means, and resources. When the quality of treatment and professional human resources is better, the hospital utilization tends to increase (Health Profile of Malang Regency, 2005-2007)

Preliminary results of a survey on patients who seek treatment in Kanjuruhan Kepanjen Hospital Malang Regency, which is determined at the beginning of treatment, was received by the clerk at the front lines until completed and allowed to go home or otherwise to be hospitalized, show that only $50 \%$ of respondents stated that the hospital cares about the society. This means that patients/ the society perceive that the image of the hospital is not good. This shows that the service delivery system which includes physical support and contact personnel influence the company's image. The quality of doctors, nursing facilities and technology, diagnostics facilities, the overall quality of care, interpersonal attention, awareness of staff to the personal needs of the patient and the hospital experience, location and cost, and also ease of location, influence the image of the hospital, the patient's satisfaction and loyalty.

\subsection{Limitations of The Problem}

1. Does the delivery of service which consists of physical support and contact personnel influence the image of Kajuruhan Kepanjen Hospital Malang Regency?

2. Does the delivery of service which consists of physical support and contact personnel influence the patients satisfaction of Kajuruhan Kepanjen Hospital Malang Regency?

3. Does the image of the hospital influence the patients satisfaction of Kajuruhan Kepanjen Hospital Malang Regency?

4. Does the image of the hospital influence the patients loyalty of Kajuruhan Kepanjen Hospital Malang Regency?

5. Does the patients satisfaction influence the patients loyalty of Kajuruhan Kepanjen Hospital Malang Regency?

\subsection{Study Objectives}

The objectives of the study are to identify and review the influence of the delivery of service to the image of the hospital and patients satisfaction, the influence of the hospital image to patients satisfaction, and also the influence of the hospital image and patients loyalty of Kajuruhan Kepanjen Hospital Malang Regency. 


\section{Theoretical Review}

\section{1. Service Delivery System}

According to Lovelock and Wright (2007), a service business is viewed as a service operation system and a service delivery system. A service operation system is a component which is included in the whole service business system, where the inputs are processed and the service product elements are created by human resources component and physical component.

The important components of service marketing namely people, process, and physical evidence are important elements in delivering the service offered and play a significant role in doing "tangibilize in the intangible". The service quality in a hospital service outside the related competences that forms the patients experience in health care is by giving service excellence, i.e. an attitude or a way of an employee or a health worker in serving the patients satisfactorily in line with the goals and benefits of service results i.e. Speed, accuracy, hospitality, and comfort.

\subsection{Image}

Keller (1993) defined a company image as a perception of a company as a company picture restrained in the customer's memory. The image and awareness are directed to two components of image knowledge. The whole formed perception (the conclusion of the image/ brand) in the customer's mind are caused by brand physic, name, symbol, display, and reputation for bank service. The factors of company image variable according to Keller (1993) are three factors namely corporate image, user image, and product image.

\subsection{Customer Satisfaction}

Customer satisfaction depends on the estimate product performance in giving the grade, relatively to the customer expectation. The customer is satisfied when the performance meets the expectation. The customer is dissatisfied when the product performance is much lower than what is expected (Kotler and Armstrong, 2009). The satisfaction felt by the customer consists of satisfaction of the product and satisfaction to the information used to choose the product. Each form is called satisfaction indicator and information satisfaction that influence the customer loyalty ( Spreng et al., 1996).

\subsection{Loyalty}

Customer loyalty is a concept that is studied more in customer behavior study. Customer loyalty has two elements namely behavior element and attitude. In the approach of behavior element, the definition of loyalty becomes shallow. Loyalty is is based on buying pattern only, and this approach defines loyalty in accordance with buying level of certain product or brand in a period. Moven and Minor (2007) defined brand loyalty as how far a customer shows a positive attitude toward a brand, has a commitment to a brand, and wants to keep buying in the future. Brand loyalty is influenced directly by the satisfaction or dissatisfaction to a product which is accumulated in a period as the perception of a product quality.

\subsection{Study Model}

The proposed study model is shown in Picture 1.

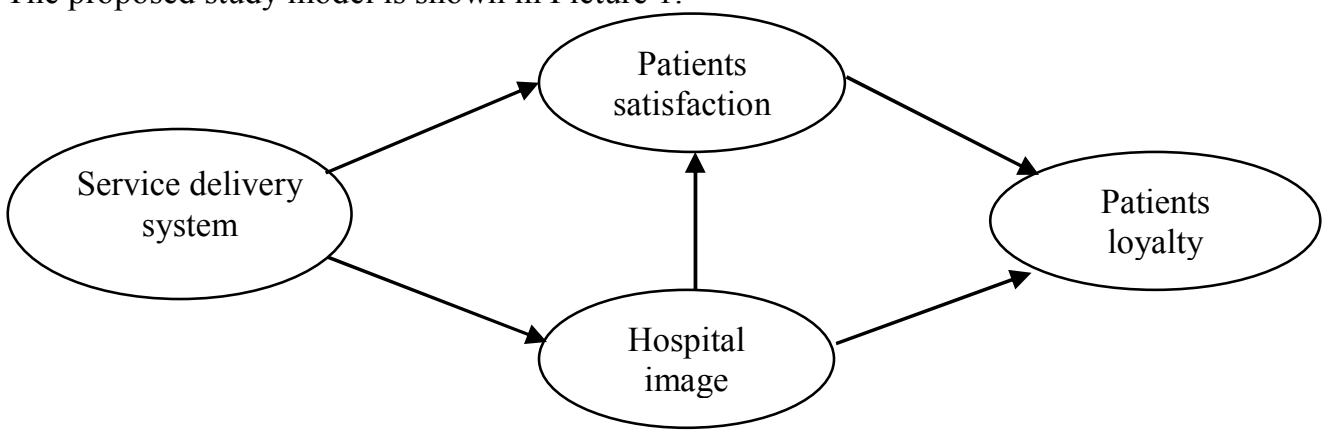

Picture 1. Study Model

\subsection{Study Hypothesis}

H1 : the delivery service system has significant influence to the hospital image of Kanjuruhan Kepanjen Hospital Malang Regency.

$\mathrm{H} 2$ : the delivery service system has significant influence to patients satisfaction of Kanjuruhan Kepanjen Hospital Malang Regency.

H3 : the hospital image has significant influence to patients satisfaction of Kanjuruhan Kepanjen Hospital 
Malang Regency.

H4 : the hospital image has significant influence to patients loyalty of Kanjuruhan Kepanjen Hospital Malang Regency.

H5 : the patients satisfaction has significant influence to patients loyalty of Kanjuruhan Kepanjen Hospital Malang Regency

\section{RESEARCH METHODS}

The population of this study is all patients of Kanjuruhan Kepanjen Malang Regency. The number of samples is based on Hair et al. (2010) who stated that the minimum data for multi-variant analysis technique is at least 100 samples. Thus, the samples used in this study are 210 patients. The determination of samples in this study is purposive sampling i.e. The researcher uses his/her own consideration (using adequate knowledge of population) to choose the samples. The analysis data technique used is Structural Equation Modeling (SEM).

\section{RESULTS AND DISCUSSION}

4. 1. Model Analysis Result

This study applies Structural Equation Modeling (SEM) analysis. The analysis results are shown in Picture 1 and Table 1.

Picture 1. SEM Beginning Step

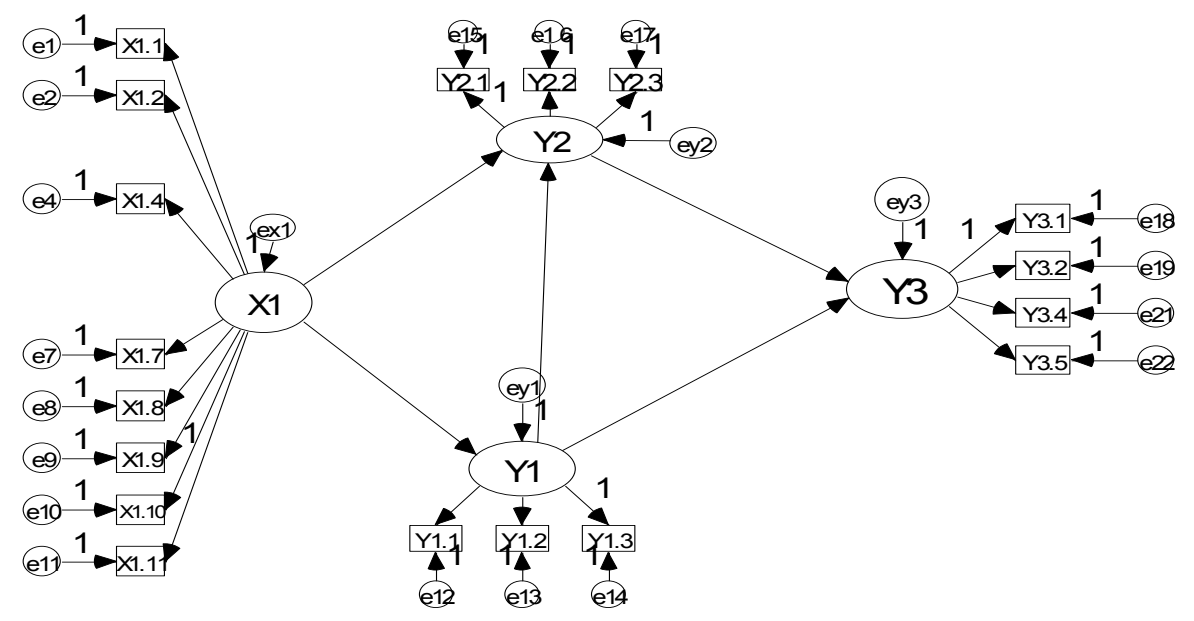

Table 1. Goodness of Fit Beginning Model Test

\begin{tabular}{llll}
\hline \multicolumn{1}{c}{ Criteria } & \multicolumn{1}{c}{ Cut-of Value } & \multicolumn{1}{c}{ Model Result } & \multicolumn{1}{c}{ Information } \\
\hline Chi-Square & Expected low & 299,207 & Not accepted \\
Probability & $\geq 0.05$ & 0,000 & Not accepted \\
RMSEA & $\leq 0.08$ & 0,079 & Accepted \\
GFI & $\geq 0.90$ & 0,865 & Not accepted \\
AGFI & $\geq 0.90$ & 0,823 & Not accepted \\
CFI & $\geq 0.95$ & 0,901 & Not accepted \\
\hline
\end{tabular}

Source: analysis result SEM (2012)

The analysis result of SEM early step shows that the beginning model is proposed based on the unacceptable theory, because there is only one good requirement (not supported by empirical data in the field) so the result is not fit. Then, the beginning model is modified with a guidance of modification indices which must be supported by relevant theory. The result is shown in Picture 2 Table 2. 


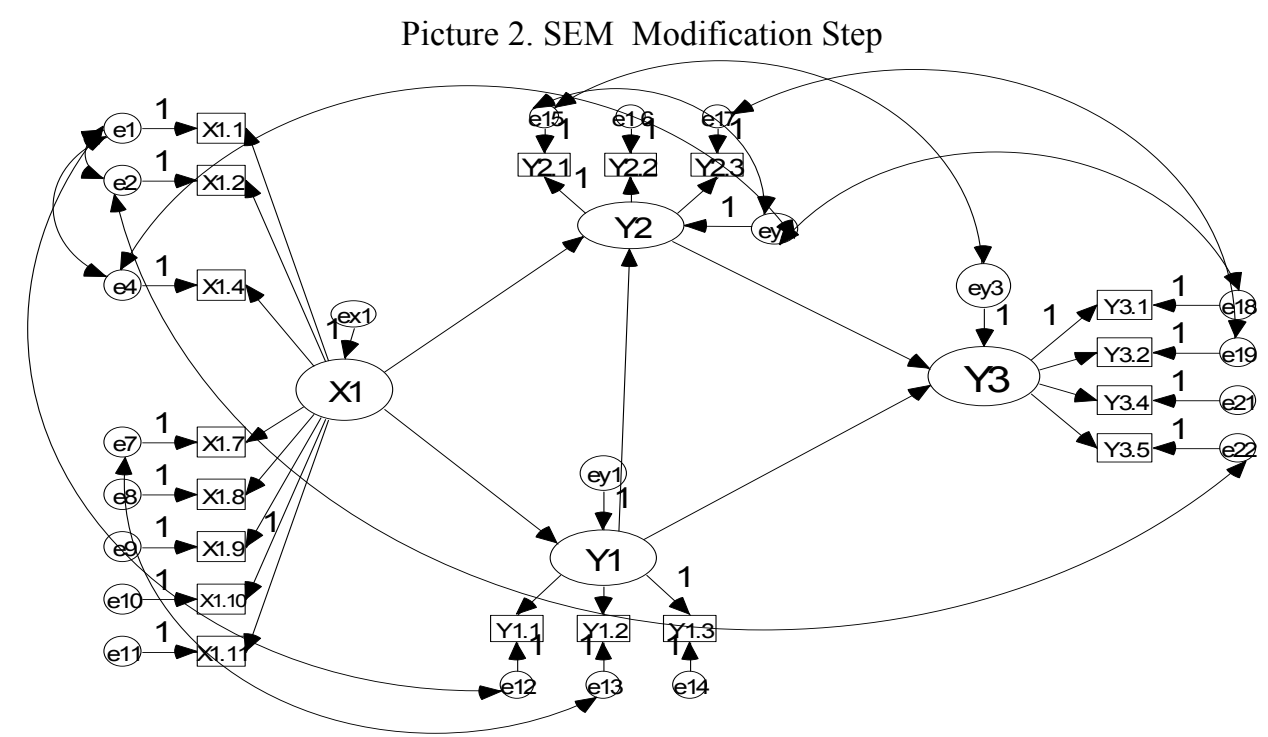

Table 2. Goodness of Fit Modification Model Test

\begin{tabular}{llll}
\hline \multicolumn{1}{c}{ Criteria } & \multicolumn{1}{c}{ Cut-of Value } & \multicolumn{1}{c}{ Model Result } & \multicolumn{1}{c}{ Information } \\
\hline Chi-Square & Expected low & 179,651 & Accepted \\
Probability & $\geq 0.05$ & 0,000 & Not accepted \\
RMSEA & $\leq 0.08$ & 0,048 & Accepted \\
GFI & $\geq 0.90$ & 0,917 & Accepted \\
AGFI & $\geq 0.90$ & 0,882 & Quite Accepted \\
CFI & $\geq 0.95$ & 0,966 & Accepted \\
\hline
\end{tabular}

Source: analysis result SEM (2012)

Table 2 shows that six criteria used to assess whether a model is fit or not, only one criteria that is quite adequate. This can be said that the model can be accepted, meaning that there is suitability between the model and the data.

\subsection{Causal Relationship between Latent Variables}

Table 3. Causal Relationship between Latents Variables

\begin{tabular}{|c|c|c|c|}
\hline \multicolumn{2}{|c|}{ Causal Relationship } & $\mathrm{P}$ value & Loading Factor \\
\hline Hospital Image & $<---\quad$ Service Delivery & 0,000 & 0.968 \\
\hline Patients Satisfaction & Hospital Image & 0,050 & 1.679 \\
\hline Patients Satisfaction & Service Delivery & 0,378 & -0.732 \\
\hline Patients Loyalty & $<---$ Hospital Image & 0.047 & 1.379 \\
\hline Patients Loyalty & $<---\quad$ Patients Satisfaction & 0,004 & 2.148 \\
\hline
\end{tabular}

Source: Analysis Result SEM (2012)

\section{3. Hypothesis Test Result}

The hypothesis test is done by comparing probability grade (p) of each latent variable with $0,05(\alpha=$ significant) in which it is stated as significant if pv latent variable is smaller or the same with $0,05(p \leq 0,05)$. Table 3 shows:

1. Service delivery system variable (X) has positive and significant influence to hospital image (Y1), with PV grade $=0,000<0,05(\alpha)$, and has a path coefficient 0,968 .

2. Service delivery system variable (X) has positive but not significant influence to patients satisfaction (Y2), with PV grade $=0,378>0,05(\alpha)$, and has a path coefficient $-0,732$.

3. Hospital Image variable (Y1)has positive and significant influence to patients satisfaction (Y2), with PV grade $=0,05 \leq 0,05(\alpha)$, and has a regression coefficient 1,679.

4. Hospital image variable (Y1) has positive and significant influence to patients loyalty (Y3), with PV grade $=0,047<0,05(\alpha)$, and has a regression coefficient 1,379.

5. Patients satisfaction variable (Y2) has positive and significant influence to patients loyalty (Y3), with PV grade $0,004<0,05(\alpha)$, and has a regression coefficient 2,148 . 


\section{4. Indirect Influence Analysis}

Table 4. Indirect Influence of Latent Variables

\begin{tabular}{llccc}
\hline & Latent Variable & Patients Satisfaction (Y2) & Patients Loyalty (Y3) \\
\hline 1. & $\mathrm{X}$ & $\mathrm{Y} 2$ (via Y1) & $0,968 \times 1,679=1,625(\mathrm{~S})$ & - \\
2. & $\mathrm{X}$ & $\mathrm{Y} 3$ (via Y1) & - & $0,968 \times 1,379=1,335(\mathrm{~S})$ \\
3. & $\mathrm{X}$ & $\mathrm{Y} 3$ (via Y1 \& Y2) & - & $0,968 \times 1,679 \times 2,148=3,491(\mathrm{~S})$ \\
\hline
\end{tabular}

The explanation of indirect influence of latent variables are as follows:

1. The indirect effect of service delivery system (X) to patients satisfaction (Y2) via hospital image (Y1) has indirect positive and significant influence $1,625(0,968 \times 1,697)$. This shows that the service delivery system variable $(\mathrm{X})$ indirectly (via hospital image) has significant influence to patients satisfaction of Kanjuruhan Kepanjen Hospital Malang Regency (Y2) whereas the direct influence is not significant.

2. The indirect effect of service delivery system (X) to patients loyalty (Y3) via hospital image (Y1) has indirectly positive and significant influence that is $1,335(0,968 \times 1,379)$

The indirect effect of service delivery system (X) to patients loyalty (Y3) via hospital image (Y1) and patients satisfaction (Y2) has indirectly positive and significant influence that is $3,491(0,968 \times 1,679 \times 2,148)$.

\section{Discussion}

1. The Influence of Service Delivery to Hospital Image (H1)

The first hypothesis is proven that the service delivery system with room design, waiting room comfort, ease of being informed, service tools, other supporting means (public telephone, ATM, Bank) indicators, and the availability of parking area, timeliness of service, patient acceptance procedure, and the communication between the health workers and the patients has significant influence to hospital image of Kanjuruhan Kepanjen Hospital Malang Regency. Tis conclusion is based on the grade of PV $=0,000<0,05$ (significant level $\alpha=0,05$ ), with path coefficient 0,968 .

This is in accordance with Nguyen and Leblanc (2002) that the service delivery system which includes physical support and contact personnel has influence to company image. In addition, this is also in line with Cooper (1994), where doctor quality, care and technology facilities, diagnostics facilities, whole care qualities, interpersonal attention, staff awareness to patients personal needs and hospital experience, location, costs, ease of patient location influence the hospital image.

The service delivery system is a communication system formed by physical support dimension and contact personnel dimension. Both physical support and contact personnel become very important in supporting the formation of hospital image. The service quality of hospital service outside the related competences that forms the patient experience in health care is by giving service excellence, i.e. an attitude or way of an employee in giving service to patients satisfactorily, according to the goals and benefits of the service results namely speed, accuracy, hospitality, and comfort. The four basic elements are a unit of integrated service, meaning that a service becomes imperfect if there is one of elements that is ignored.

2. The Influence of Service Delivery to Patients Satisfaction (H2)

The second hypothesis is not proven that the service delivery system does not have significant influence to patients satisfaction of Kanjuruhan Kepanjen Hospital Malang Regency. This conclusion is based on the grade of $\mathrm{PV}=0,378>0,05$ (significant level $\alpha=0,05$ ), with path coefficient $-0,732$. This result is not in line with Shamdasani and Balakrishnan (2000), who concluded that physical support and contact personnel influence the customer satisfaction. In this study, physical support owned by the hospital less influence the forming of hospital service delivery system, meaning that the patients think that reliability is more important than facilities and infrastructures owned by the hospital. The same opinion is also put forward by Lupiyoadi (2006) that in hospital service, the reliability and responsiveness of the health workers are much more dominant that the hospital interiors.

3. The Influence of Hospital Image to Patients Satisfaction (H3)

The third hypothesis is proven that the hospital image- with the indicators of patients impressions to the hospital, the patients trust to the hospital, and the health workers ability - has significant influence to the satisfaction of patients of Kanjuruhan Kepanjen Hospital Malang Regency. This conclusion is based on the grade of PV = $0,050 \leq 0,50$ (significant level $\alpha=0,05$ ), with path coefficient 1,679. The study result is in line with the result of the research done by Selnes (1993) and Bloemer et al. (2002).

Selnes (1993) concluded that a company image influences the customer satisfaction and loyalty. Bloemer et al. (2002) stated that an image influences customer satisfaction. Besides, this study also supports Mc Daniel et al. (2007) who stated that the purchase of a brand results in satisfaction for a customer, that is compared to the expectation of a brand strength potential. Also the expectation becomes the foundation which underlies the first decision made by a customer. 
4. The Influence of Hospital Image to Patients Loyalty (H4)

The fourth hypothesis is proven that hospital image has significant influence to patients loyalty of Kanjuruhan Kepanjen Hospital Malang Regency. This conclusion is based on the grade of $\mathrm{PV}=0,047 \leq 0,50$ (significant level $\alpha=0,05$ ), with path coefficient 1,379 . The study result is in line with the result of the research done by Selnes (1993) and Bloemer et al. (2002). Selnes (1993) showed that a company image influences the customers satisfaction and loyalty, meaning that the company (Kanjuruhan Kepanjen Hospital Malang Regency) influences the patients loyalty.

This study result indicates the support to the theories which stated that there is a significant influence of image to patients loyalty. Patients will be loyal if the patients view a hospital as a good hospital. The influence of company image to the patients which is shown in Bloemer et al. (2002) who concluded that an image does not have direct influence to customers loyalty, but it is only a moderator variable between quality and customers.

This study shows that a company image has direct influence to customers loyalty and also acts as a moderator variable between service delivery system and customers loyalty, meaning that image variable can be either endogenous variable or exogenous variable. This study is also in line with Nguyen and Leblanc (2002) who stated that a company image has positive influence to customers loyalty in three sectors (telecommunication, retail, and education).

5. The Influence of Patients Satisfaction to Patients Loyalty (H5)

The fifth hypothesis is proven that patients satisfaction has significant influence to patients loyalty of Kanjuruhan Kepenjen Hospital Malang Regency. This conclusion is based on the grade of PV $=0,004 \leq 0,50$ (significant level $\alpha=0,05$ ), with path coefficient 2,148. Athis study is in line with Bloemer et al. (2002) and Spreng et al. (1996).

Bloemer et al. (2002) concluded that image influences customers satisfaction, satisfaction influences trust, and trust influences customers commitment (loyalty). Spreng et al. (1996) stated that overall customers satisfaction consists of the satisfaction to the product itself and the satisfaction to the information used to choose the product. Each form is named satisfaction indicator and information satisfaction which influence customers loyalty.

Customer satisfaction is a key for business profit and customers loyalty is a key for continuing satisfaction. The satisfied customers tend to be loyal. This is also applied in health agency. The patients who are satisfied with the hospital service will tend to be loyal to the hospital. Based on the result of this study, patients loyalty is much influenced by patients satisfaction. Besides the direct influence of patients satisfaction, patients loyalty is also influenced directly by image and indirectly by service delivery system through image as a moderator variable. Patients loyalty is a point which is expected by service company because customers loyalty is a benchmark of the success of service delivery system and company image.

\section{CONCLUSION}

The image of Kajuruhan Kepanjen Hospital Malang Regency has positive and significant influence to patients satisfaction and loyalty. Patients satisfaction has positive and significant influence to patients loyalty.

\section{SUGGESTION}

Physical support owned by the hospital can change patients orientation about reliability hospital than facilities and infrastructures owned by the hospital.

\section{REFERENCES}

Bloemer, Ruyter, and Peter, 2002, Investigating Drivers of Bank Loyalty: the Complex Relationship between Image, Service Quality and Satisfaction, Journal of Marketing, Vol. 9, No.3, pp. 23-42.

Cooper, Joseph, 1994, Measuring Service Quality: A Reexamination and Extension. Journal of Marketing, Vol. 56 (July), pp. 55-68.

Hair, J.F., Anderson R.E., Tatham R.L., and Black W.C., 2010, Multivariate Data Analysis, Seventh Edition, Pearson Prentice-Hall International Inc., New Jersey.

Keller, K. L., 1993, A Conceptualizing, Measuring, and Managing Customer-Based Brand Equity, Journal of Marketing Research, Vol. 29, pp.1-22.

Kotler, Philip, and Gary Armstrong, 2009, Prinsip-Prinsip Pemasaran, Edisi Terjemahan, Erlangga, Jakarta.

Lovelock, Christopher H., and Lauren K. Wright, 2007, Manajemen Pemasaran Jasa, Cetakan Kedua, Indeks, Jakarta.

Lupiyoadi, Rambat, 2006, Manajemen Pemasaran Jasa, Edisi Kedua, Penerbit Salemba Empat, Jakarta.

McDaniel C., Hair J.F., dan Lamb C.W. Jr, 2007, Pemasaran, Edisi Terbatas (Terjemahan). Prentice Hall, New york.

Mowen, John C., dan Michael Minor, 2007, Customer Loyalty, Edisi Ketiga, Erlangga, Jakarta.

Nguyen, N., and Leblanc G., 2002, The Mediating Role of Corporate Image on Customers' Retention Decisions: 
An Investigating in Financial Service. The International Journal Marketing. Vol. 16. pp 52-74.

Selnes, Fred, 1993, An Examination of The Effect of Product Performance on Brand Reputaion, Satisfaction and Loyalty, European Journal of Marketing, Vol. 27 (May) pp.19-36.

Shamdasani, Prem N., and Audrey A. Balakrishnan, 2000, Determinants of Relatioship Quality and Loyalty in Personalized Services, Journal of Marketing, Vol. 6 (June) pp.390-407.

Spreng, Richard A., Scott B. MacKenzie, and Richard W. Olshavsky, 1996, A Reexamination of the Determinants of Customer Satisfaction, Journal of Marketing, Vol. 9 (July), pp. 15-32. 